\title{
Correction to: Muscle and tendon morphology alterations in children and adolescents with mild forms of spastic cerebral palsy
}

Annika Kruse ${ }^{1}$, Christian Schranz ${ }^{2}$, Markus Tilp ${ }^{1 *}$ and Martin Svehlik ${ }^{2}$

\section{Correction}

Following publication of the original article [1], the author requested for an acknowledgement to retrospectively be added to the 'Acknowledgements' section of the article [1].

The addition is:

"The authors acknowledge the financial support by the University of Graz."

Thank you.

\section{Author details}

'Institute of Sports Science, University of Graz, Mozartgasse 14, 8010 Graz, Austria. ${ }^{2}$ Department of Paediatric Surgery, Medical University of Graz, Auenbruggerplatz 34, 8036 Graz, Austria.

Published online: 18 August 2018

\section{Reference}

1. Kruse, et al. Muscle and tendon morphology alterations in children and adolescents with mild forms of spastic cerebral palsy. BMC Pediatr. 2018;18:

156. https://doi.org/10.1186/s12887-018-1129-4.

\footnotetext{
*Correspondence: markus.tilp@uni-graz.at

${ }^{1}$ Institute of Sports Science, University of Graz, Mozartgasse 14, 8010 Graz,

Austria
} 